UDC 130.2:37.013.73:159.955.1

\author{
I. V. KARPENKO ${ }^{1^{*}}$, A. A. GUZHVA ${ }^{2 *}$ \\ ${ }^{1 *}$ V. N. Karazin Kharkiv National University (Kharkiv, Ukraine), e-mail i.v.karpenko@karazin.ua, \\ ORCID 0000-0001-9425-149X \\ ${ }^{2 *}$ V. N. Karazin Kharkiv National University (Kharkiv, Ukraine), e-mail aguzhva@ukr.net, ORCID 0000-0001-5821-8182
}

\title{
Human Being in the Dimension of the Psychosociocultural Matrix of Philosophizing
}

Purpose. The article highlights the demand for critical thinking in everyday life at the present stage of development of globalized culture and emphasizes the role of philosophy as a source of rationality. Philosophizing, which is determined by the psychosociocultural matrix, sets the toposes, vocabulary and rhythms of meaning making, their preservation and transformation. The purpose of the article is to concretize the practices of socio-cultural communication, primarily through the social institute of education, where individuals interact with the psychosociocultural matrix of philosophizing, which mediate the general and individual level in philosophical culture. Theoretical basis of the study are cultural anthropology and phenomenological methods. Originality of the study: based on the philosophy of intersubjectivity, we actualized the rational grounds for formation of adequate judgments in modern culture at the level of everyday life. This justifies the inevitability of the spread of various forms and types of philosophical education, philosophical thinking, ideas and values developed in philosophical communities beyond the narrow circle of professional philosophers. This implies the systemic involvement of philosophers as professionals of meaningmaking in solving problems in various non-academic fields - politics, economics, law, etc. The formation of skills of philosophical critical thinking in the process of preparing young people for active civil life is no less important aspect of this. Conclusions lead to an understanding of the existential importance of philosophy and philosophizing and the need for organized forms of knowledge transfer such as the Faculty of Philosophy of the Classical University. There is a mutual interest and interaction of the general culture of society and philosophy as a special kind of culture. Because philosophy actively configures other forms of culture, contributes to the creation of sociocultural identities precisely because of its ability to conceptually reproduce the core of the psychosociocultural matrix that underlies the existence of all these different forms within one society. The sociocultural macro level of philosophical spiritual practices is formed by the psychosociocultural matrix of the philosophical tradition, which retains its longevity from the emergence of philosophy and goes through its history, demonstrating the features of the national reception of philosophy as a national-specific embodiment of sociocultural macro level of the psychosociocultural matrix.

Keywords: human being; personality; critical thinking; psychosociocultural matrix; philosophizing; philosophical education; sociocultural identity; meaning making; everyday life

\section{Introduction}

The issue of presentation of culture as values, symbols, ideas and practices common for a certain community is the core of cultural communication for each person and in each human generation and is provided within the social institution of education. It is not only the internalization of norms and values or the general mechanism of socialization, but the specific practices of how the culture existing in society and the social institutions are refracted through the institutions of education in a particular educational communication. This sets the diachronic and synchronous sections of the culture presentation. This culture, which has outgrown the archaic level, is not spontaneous, but is the work of specific people and social communities creating their own sociocultural identity through the inculcation of specific patterns and practices in each person and in each human generation. It forms the semantic part of educational communication in the direct interpersonal interaction of people involved in this process.

The quintessence of the problem of a certain length and continuity of culture transmission through education can be revealed through the problem of psychosociocultural matrix of philos- 
ophizing as the translation of philosophical knowledge through philosophical education. From this point of view, philosophizing appears as a model of basic practices for the formation of meanings - their fixation, preservation and variable transformation. Psychosociocultural matrix sets specific topos, vocabulary and rhythms of philosophizing, and thus affects not only the direct philosophical space, but also the meaning-making and rational human activity in everyday life. The relevance of studying the forming factors of certain types of rational thinking and behavioural models is due to the high demand for critical thinking in the world of information wars, the spread of populism and consumerism, where even ordinary news watching requires a certain logic and hygiene of thinking.

Defining philosophy as an individual spiritual quest and paying tribute to man's natural desire for wisdom, it is appropriate to remember that philosophers become philosophers not at once, not suddenly, but through a gradual involvement in the values, ideas and practices of a particular philosophical community. So the problem is to find ways to ensure a successful relationship between the general in culture, represented by its psychosociocultural matrix and individual culture, which embodies the specifics of human development.

\section{Purpose}

To determine specific practices of philosophizing, which are the special thing that mediates the general and individual in philosophical culture and appear as a connecting link through which individuals interact with the philosophical psycho-socio-cultural matrix. The methodology is based on the cultural-anthropological approach, which is supplemented by the phenomenological method.

\section{Statement of basic materials}

\section{Reactualization of critical thinking}

Peculiarities of man, as a biological being, determine the absence of a genetic mechanism of imitation of complex patterns of behaviour, so the basis of his socio-cultural identity is formed in the process of upbringing and education. The main importance of philosophical education and philosophizing (as the ability to analyse and make judgments that carry important meanings in life), sharpened in the era of digital media and social networks. The degree of loneliness, confusion, abandonment of man after a certain disengagement of the world (according to M. Weber), caused by the wave of modern rationalization, greatly increased in the historical situation of postmodernism and related phenomena of posthuman, post-truth, post-state, etc. against the background of globalization. The new technologies can produce new objects, which imitate a new "life" around us (Liberati, 2016). The constant transformation of social, cultural identities, the dominance of consumption and entertainment in everyday life significantly complicate the interpretation of information signals received by the individual from various sources, leading to uncritical, evaluative, purely emotional perception and analysis of information, including his own place in culture and the Universe. Relying almost exclusively on the sensory basis of thought formation, based on experienced emotions, leads to the resuscitation of archaic practices of community formation, namely, in the words of M. Maffesoli (1996), in the form of "the newest tribalism", which is actualized through the aesthetic paradigm of "the 'loss' in a collective subject" (p. 11). The emergence of such a way of forming communities influenced the overall architecture of the cultural sphere, contributing to the flourishing of popular culture, political 
populism and other social practices (Guzhva, 2021). However, emotional evaluation on the "like/dislike" scale (as a basis for decision-making and meaning-making) is not always a sufficient argument or, in the words of E. Husserl (1939), "the condition of all obviousness" ("the self-obviousness ... has its sensory foundation in the conditions making possible the creation of the obviousness of the last substrates of judgment") (p. 37), because the worlds in the age of global circulation of information and cultural practices - from country to country, from community to community - are significantly different from each other, so only the sensory-emotional experience is not able to serve as a basis for both its obviousness and the generation of new meanings.

At the same time, modern culture is characterized by a transition from the modern epoch inherent cultivation of the individual subject, who knows and forms judgments about the world, to the philosophy of intersubjectivity, which deals with the search for common meanings, so the emphasis in the production of judgments shifts to communication between individuals (Tavory, 2018; Yermolenko, 2020), the common interpretation and a certain universalization and normalization of values that are used and formed in the process of such communication (Schütz \& Luckmann, 2018). By the way, in the light of intersubjectivity, "neo-tribalism" of M. Maffesoli appears simply as a special extreme case of intersubjective communication. However, it seems that the pendulum of cultural processes began to move in the opposite direction and the need for formalization, as well as for conceptual apparatus recognized by all subjects of communication to produce common values and make vital decisions forces members of society to actively seek the foundations of critical thinking, which, as we know, is brought up the best by philosophy (Karpenko, 2009).

Recourse to philosophy as a source of critical thinking is quite appropriate when offering educational programs and modules that prepare young people to participate in active social life and responsible citizenship, as highlighted, in particular, in the publication "Theory and Practice of Citizenship Education" (Veugelers \& Groot, 2019). Conscious citizenship is associated with democratic institutions and requires a certain set of knowledge. This is already well understood in European society and similar educational projects are implemented in various versions, in particular, as part of secondary school programs. Among the basic legal information, articulation of democratic values and equality policy, a mandatory component of educational programs is familiarity with the philosophical concepts of common (including - universal) values, justice, tolerance, social transformations, which together form "a dynamic field with different social, moral, cultural and political perspectives" (Veugelers \& Groot, 2019, p. 17). Moreover, the authors of the publication critically point out that such an important process for citizenship as learning common values is not sufficiently embodied in educational practices compared to other topics and subjects (Veugelers \& Groot, 2019, p. 23).

The issue of implementation in the Ukrainian socio-cultural environment of educational programs and practices on the values of human existence, in particular, such as justice and tolerance, and in general the promotion of rational thinking is a matter of developing critical thinking of Ukrainian citizens, on the one hand, and effective adaptation to changing conditions of globalization processes together with the improvement of social interaction in Ukraine itself, on the other. A systematic and consistent solution to these issues is possible only through recourse to philosophy. Thus, civic values in a democratic society are quite clearly correlated with academic values and virtues (Boychenko, 2014). Different levels of critical thinking - from academic to everyday one - are rooted in general culture through the development of philosophical thinking, 
which is the result of intellectual individual and collective efforts, interactions and interinfluences mediated by special discursive practices, including the creation of sociocultural identities. At one time, there was proposed a concept of psychosociocultural matrix as a sensory basis capable of determining philosophizing, which due to its roots in the deep layers of culture can be successfully preserved, sufficiently transformed, adaptively responding to new challenges, and providing communication and common values for different situations.

\section{Circulation of philosophical thinking in the cultural space}

Psychosociocultural matrix as a sensory basis for structuring the world of philosophy, according to the author, "contains thousands of unexplored opportunities, inconsistencies, oppositions, which are never covered by one philosophy. One philosophy meaning both one of many philosophies, and philosophy alone, excluding other spiritual formations of culture" (authors' transl.) (Karpenko, 2006, p. 196). Philosophy always has its own sociocultural matrix - established in a particular society of philosophizing. Philosophical psychosociocultural matrix may have many non-philosophical embodiments, as shown by the history of philosophy, however, it still needs to reproduce the actual philosophical community, the community of philosophers, as the bearers of this matrix and as its co-creators and guarantors of its self-reproduction.

In the light of the public demand for critical thinking, the point is that philosophy is important not only for the preservation of its own sociocultural matrix - philosophy can contribute to the preservation and successful reproduction of other psychosociocultural matrices. There is a counter-interest in the general culture of society and philosophy as a special kind of culture: philosophy extends its influence to other forms of culture precisely because of its ability to conceptually reproduce the core of the psychosociocultural matrix that underlies the existence of all these different forms within one society. To some extent, Karl Jaspers (2009) wrote about this in his "Psychology of Worldviews (Psychologie der Weltanschauungen)". However, Jaspers focused on worldviews as self-sufficient phenomena, while we focus on certain socio-cultural practices through which any worldview can function and transform. For Jaspers, these worldviews play a fundamental role - they act as a core surrounded by the creation of meanings. We proceed from the axiom of the philosophy of communication, according to which any possible meanings, including worldviews, depend on social communication. For Jaspers, worldviews, as psychosociocultural matrices, are certain historical types transformable into the status of ideal timeless types, which, although emerged at different times, but in modern society coexist as the competing and complementary forms of culture. For us, worldviews in modern society appear less and less historically determined, but are increasingly determined by existing sociocultural practices.

Worldviews, of course, are not created in certain socio-cultural practices, but they undergo significant changes and modifications in them, and most importantly - in social communication, people can change their own worldview to another one. This is beyond the power of the individual: even in the exceptional cases of charismatic leaders, they only initiate the emergence of a new worldview, but can only establish it through the support of their followers and through communication with them. Thus, the thing not surmountable for an individual is a very realistic task for groups of like-minded people, especially if they form a single social community. The more meaningfully and consistently such a community acts, the larger and more convincing the result of its socio-cultural influence will be (Kalmykova, Kharchenko, Volzhentseva, Kalmykov, \& Mysan, 2020). In this sense, in our opinion, it is worth talking about philosophical thinking as the quintessence of culture: as a result of the collective influence of the community of philoso- 
phers on society and culture of their time. Philosophers are not archivists of their time who make an intellectual "extract" from their contemporary culture - on the contrary, they create those ideas, images and values that inspire their contemporaries not just to perceive their time and culture as something in common, but to actively confirm this belief, to make the desires come true.

It is philosophers who generalize in concepts various versions of the embodiment of a certain sociocultural matrix, thus ensuring its self-reproduction - as the sociocultural material used to collect one matrix, through some additions and combinations can be used to collect another matrix. Thus, almost the same original ideas and cultural symbols gave birth to three different religions - Judaism, Christianity, Islam, together with specific to each of them versions of their philosophical justification, explanation and legitimacy. In order for different cultural practices not to "fall out" of the psychosociocultural matrix that gave rise to them, there are needed additional special conceptual efforts: so to say - a time to cast away stones, and a time to gather stones together.

Thus, philosophy (just as individual spiritual pursuits) carries out variations of the psychosociocultural matrix, which underlies the functioning of human culture and expresses the unity of those social norms as collective long-term and sustainable cultural practices and social values, as the interest of the era. Briefly speaking, it is through specific socio-cultural practices of specific social communities that individual countless variations of society originate from the general culture of society, and, conversely, it is in these practices and communities that these individual variations again form a single culture of society. If we turn to Georg Hegel (2004), there is no doubt that these practices and communities play the role of "special", which mediates the "general" and "individual" in culture. That is, the practices of social communities are this middle link between the macro- and micro-levels of spiritual practices in culture. However, most such practices are carried out spontaneously. While philosophical communities are one of the few in society (alongside, perhaps, communities of artists and politicians) who claim to conceptualize such practices.

\section{Faculty of Philosophy as a socio-cultural centre of philosophizing}

For example, today such an obvious community is the Faculty of Philosophy of the Classical University. In ancient times, it could be a private philosophical school of Plato, Aristotle, Epicurus or some rich Roman. In the Middle Ages, it would most likely be a Catholic monastery, and since the Renaissance - an association of intellectuals interested in philosophy, become more or less informal, spread in various spheres of public life - art and politics, science and engineering, generate religious pursuits of Protestantism and revolutionary movements of national selfawareness. However, all this time the university and its Faculty of Philosophy have been involved in this socio-cultural turmoil. It is one of the first and obligatory faculties of each university but, unfortunately, today one has to prove this and make considerable efforts for the faculty restoration (Karpenko \& Holikov, 2011).

We should note that philosophy, in contrast to religion as a competitive system in its understanding of existence, at least requires from its neophytes a certain fairly high intellectual level of knowledge and skills. When it comes to philosophizing professionals, the constant doxa is the statement about the identity of the ideas and values that the philosopher declares to his/her life practices and strategies. Conceptualization of philosophical knowledge transfer practices is most often embodied in the process of live communication, and in groups, such as mini-communities, because in the presence of other people there is increased emotionality of individuals, which 
simplifies internalization, both individual and intersubjective. These human peculiarities in psychology are well known as elements of the phenomenon of mass, and in the philosophical sciences have recently been conceptualized as a phenomenon of social ecstasy (Guzhva, 2016). These conditions activate mutual projections-identifications between teacher and students. That is why the ideas and practices of philosophizing are best transmitted from the person-real bearer of such ideas, values and practices to other persons-potential carriers of such practices, values and ideas. It is not accidental to turn to the sensory-emotional sphere of a person after stating the need for critical thinking and emphasizing the priority of rationality in this dimension, because emotions are an integral part of the human phenomenon. The problem is not the need to get rid of emotionality in the process of judgment or the formation of meaning, as seen by Rene Descartes, according to Oleg Khoma (2021). Firstly, it is almost impossible and is achieved only in abstract concepts. And secondly, it should be emphasized that not only in practice but also in theory we must avoid the extremes of the absolute opposition of rational and emotional. This avoidance is best ensured by addressing the concept of psychosociocultural matrix. In any case, the self-awareness of the individual according to all known models of identification is primarily emotional, so the establishment of the involvement of a particular individual in the philosophical community is no exception. Thus, professional philosophers, teachers of philosophy become cultural models and models of philosophizing for their students and listeners. Unlike religious spirituality, which comes "from above" from God or some other transcendent source, philosophical self-awareness and self-identification are born in educational dialogue, which gradually spreads to the entire public. And there remains only one question: is this knowledge able to properly take root and be applied in everyday life, outside of professional philosophizing?

From the classical philosophical point of view, everyday life, due to its ontological characteristics, is insensitive to philosophical ideas transcendent in relation to naive everyday routine. In the world of everyday life, non-philosophers usually have a long-standing idea that a philosopher may know something, but his knowledge means little to solve life problems and therefore has no practical use. However, to overcome this opposition, it is not a question of erasing the differences between everyday life and philosophy, but only of the fact that the time has come for philosophy to expand its opportunities to participate in real life, offering solutions to practical problems, associated with the need to apply critical thinking in everyday life. Perhaps the expected moment has come when philosophy and philosophers will fulfil their purpose, and "the result of their activities will make sense for culture as a whole" (authors' transl.) (Karpenko, 2006, p. 82), and for socio-cultural practices and the creation of socio-cultural identities in everyday life.

\section{Originality}

The statement of the demand for critical thinking in modern culture at the level of everyday life highlights the need to spread philosophical practices of rational thinking, philosophical ideas, and values developed in philosophical communities beyond the narrow circle of professional philosophers. This spread is possible not as the dissolution of philosophical communities in other social communities, but through the preservation by philosophers of their socio-cultural identity, and on this basis - through the involvement of philosophers (as experts in critical thinking and social ethics) in expert groups that are formed outside the academic space - in politics, law, economics, art, etc. Such involvement has always taken place in society, but it was unsystematic. Whereas in modern society, the role of philosophers as facilitators and moderators in finding the right solutions in various spheres of public life must become an integral part of modern communication culture. 


\section{Conclusions}

The sociocultural macro level of philosophical spiritual practices is formed by the psychosociocultural matrix of the philosophical tradition, which retains its longevity from the emergence of philosophy and goes through its entire history. However, in each country this tradition gets its own, special refraction, which depends, in particular, on the peculiarities of the national reception of philosophy - its institutional registration in the national system of education and science, the degree of culture of translation into the national language, and finally, the presence of its own national philosophical "pantheon" and its own philosophical socio-cultural identity. It is in such a nationally concrete embodiment that this socio-cultural macro level appears as a psychosociocultural matrix. If the whole world philosophical tradition is the being of philosophical culture "in itself", then in its concrete national embodiment and concrete national reception this tradition receives the being "for itself".

\section{REFERENCES}

Boychenko, M. (2014). Dignity, integrity and success: academic and civic virtues. Philosophical Thought, 5, 110-122. (in Ukrainian)

Guzhva, A. (2016). Phenomenon of public ecstatic states. Philosophy and social sciences, 1, 52-56. (in Russian)

Guzhva, A. (2021). Political populism and popular culture. Philosophical Thought, 3, 125-137. DOI: https://doi.org/ 10.15407/fd2021.03.125 (in Ukrainian)

Hegel, G. W. F. (2004). Phenomenology of spirit (P. Tarashchuk, Trans.). Kyiv: Vydavnytstvo Solomii Pavlychko "Osnovy". (in Ukrainian)

Husserl, E. (1939). Erfahrung und Urtel: Untersuchungen zur Genealogie der Logik. Prag: Academia Vlgsbuchhdlg. (in German)

Jaspers, K. (2009). Psychology of worldviews (O. Kysliuk \& R. Osadchuk, Trans.). Kyiv: Yunivers. (in Ukrainian)

Kalmykova, L., Kharchenko, N., Volzhentseva, I., Kalmykov, H., \& Mysan, I. (2020). Actualization of the Internal Speech Problems in Psycholinguistics of Communication: The Results of a Systematic Review and MetaAnalysis. Psycholinguistics, 28(1), 83-148. DOI: https://doi.org/10.31470/2309-1797-2020-28-1-83-148 (in Ukrainian)

Karpenko, I. V. (2006). Filosofskoe prostranstvo kultury. Kharkiv: V. N. Karazin Kharkiv National University. (in Russian)

Karpenko, I. V. (2009). Filosofuvannia v prostori liudskoho spilkuvannia. Philosophy of communication. Philosophy, psychology, social communication, 2, 78-83. (in Ukrainian)

Karpenko, I. V., \& Holikov, S. O. (2011). Filosofskyi fakultet: vtilennia mrii. The Journal of V. N. Karazin Kharkiv National University, Series "Philosophy. Philosophical Peripeteias", 44, 5-9. (in Ukrainian)

Khoma, O. (Ed.). (2021). "Medytatsii" Dekarta u dzerkali suchasnykh tlumachen: Jean-Marie Beyssade, Jean-Luc Marion, Kim Sang Ong-Van-Cung. Kyiv: Dukh i Litera. (in Ukrainian)

Liberati, N. (2016). Technology, Phenomenology and the Everyday World: A Phenomenological Analysis on How Technologies Mould Our World. Human Studies, 39(2), 189-216. DOI: https://doi.org/10.1007/s10746015-9353-5 (in English)

Maffesoli, M. (1996). The Time of the Tribes: The Decline of Individualism in Mass Society. London: SAGE Publications. (in English)

Schütz, A., \& Luckmann, T. (2018). The structures of life world (V. Kebuladze, Trans.). Kharkiv: Folio. (in Ukrainian)

Tavory, I. (2018). Between Situations: Anticipation, Rhythms, and the Theory of Interaction. Sociological Theory, 36(2), 117-133. DOI: https://doi.org/10.1177/0735275118777007 (in English)

Veugelers, W., \& Groot, I. de. (2019). Theory and Practice of Citizenship Education. In W. Veugelers (Ed.), Education for Democratic Intercultural Citizenship (pp. 14-41). Leiden: Brill. DOI: https://doi.org/ 10.1163/9789004411944_002 (in English)

Yermolenko, A. (2020). Interiorization of intersubjectivity in the "I"-concept and co-responsibility in transcendental pragmatics. Philosophical Thought, 6, 6-15. DOI: https://doi.org/10.15407/fd2020.06.006 (in Ukrainian) 


\section{LIST OF REFERENCE LINKS}

Бойченко М. Гідність, цілісність і успішність: академічні та громадянські чесноти. Філософська думка. 2014. № 5. С. 110-122.

Гужва А. Феномен общественных экстатических состояний. Философия и соииальные науки. 2016. № 1. C. 52-56.

Гужва А. Політичний популізм і популярна культура. Філософська думка. 2021. № 3. С. 125-137. DOI: https://doi.org/10.15407/fd2021.03.125

Гегель Г. В. Ф. Феноменологія духу / з нім. пер. П. Таращук. Київ : Вид-во Соломії Павличко "Основи", 2004. $548 \mathrm{c}$.

Husserl E. Erfahrung und Urtel: Untersuchungen zur Genealogie der Logik. Prag : Academia Vlgsbuchhdlg, 1939.

Ясперс К. Психологія світоглядів / пер. 3 нім. О. Кислюк, Р. Осадчук. Київ : Юніверс, 2009. 464 с.

Kalmykova L., Kharchenko N., Volzhentseva I., Kalmykov H., Mysan I. Actualization of the Internal Speech Problems in Psycholinguistics of Communication: The Results of a Systematic Review and Meta-Analysis. Psycholinguistics. 2020. Vol. 28. No. 1. P. 83-148. DOI: https://doi.org/10.31470/2309-1797-2020-28-183-148

Карпенко И. В. Философское пространство культуры. Харьков : ХНУ имени В. Н. Каразина, 2006. 292 с.

Карпенко І. В. Філософування в просторі людського спілкування. Філософія спілкування: філософія, психологія, соиіальна комунікачія. 2009. № 2. С. 78-83.

Карпенко І. В., Голіков С. О. Філософський факультет: втілення мрії. Вісник Харківського національного університету імені В. Н. Каразіна. Серія "Філософія. Філософські перипетї̈". 2011. № 44. С. 5-9.

"Медитації" Декарта у дзеркалі сучасних тлумачень: Жан-Марі Бейсад, Жан-Люк Марйон, Кім Сан ОнВан-Кун / уклад. О. Хома. Київ : Дух і Літера, 2021. 368 с.

Liberati N. Technology, Phenomenology and the Everyday World: A Phenomenological Analysis on How Technologies Mould Our World. Human Studies. 2016. Vol. 39. Iss. 2. P. 189-216. DOI: https://doi.org/10.1007/ s10746-015-9353-5

Maffesoli M. The Time of the Tribes: The Decline of Individualism in Mass Society. London : SAGE Publications, 1996.

Шюц А., Лукман Т. Структури життєсвіту / пер. з нім. В. Кебуладзе. Харків : Фоліо, 2018.

Tavory I. Between Situations: Anticipation, Rhythms, and the Theory of Interaction. Sociological Theory. 2018. Vol. 36. Iss. 2. P. 117-133. DOI: https://doi.org/10.1177/0735275118777007

Veugelers W., de Groot I. Theory and Practice of Citizenship Education. Education for Democratic Intercultural Citizenship / ed. by W. Veugelers. Leiden : Brill, 2019. P. 14-41. DOI: https://doi.org/10.1163/ 9789004411944_002

Єрмоленко А. Інтеріоризація інтерсуб'єктивності в "Я"-концепті та співвідповідальність у трансцендентальній прагматиці. Філософська думка. 2020. № 6. С. 6-15. DOI: https://doi.org/10.15407/fd2020.06.006

\section{I. В. КАРПЕНКО ${ }^{1 *}$, А. А. ГУЖВА ${ }^{2 *}$}

\footnotetext{
${ }^{1 *}$ Харківський національний університет імені В. Н. Каразіна (Харків, Україна), ел. пошта i.v.karpenko@karazin.ua, ORCID 0000-0001-9425-149X

${ }^{2 *}$ Харківський національний університет імені В. Н. Каразіна (Харків, Україна), ел. пошта aguzhva@ukr.net,

ORCID 0000-0001-5821-8182
}

\section{Людина у вимірі психосоціокультурної матриці філософування}

Мета. У статті висвітлена затребуваність критичного мислення у повсякденності на сучасному етапі розвитку глобалізованої культури і підкреслена роль філософії як джерела раціональності. Філософування, яке обумовлюється психосоціокультурною матрицею, задає топоси, лексику і ритми формування смислів, їх збереження і трансформації. Мета статті - конкретизувати практики соціокультурної комунікації через їх дослідження в рамках соціального інституту освіти, де відбувається взаємодія індивідуумів із психосоціокультурною матрицею філософування, яка опосередковує загальне та індивідуальне у філософській культурі. Теоретичний базис дослідження становлять культурно-антропологічний $\mathrm{i}$ феноменологічний методи. Наукова новизна дослідження: 3 опертям на філософію інтерсуб'єктивності, 
актуалізовано раціональні підстави формування адекватних суджень у сучасній культурі на рівні повсякденного життя, що обгрунтовує неминучість поширення різних форм і видів філософської освіти, філософського мислення, ідей, напрацьованих у філософських спільнотах цінностей за межі вузького кола професійних філософів. Це передбачає системне залучення філософів до вирішення питань у різних неакадемічних сферах - політиці, економіці, юриспруденції тощо. Важливим аспектом цього є формування навичок філософського критичного мислення в процесі підготовки молоді до активного громадського життя. Висновки призводять до розуміння екзистенційного значення філософії та філософування і визнання необхідності організованих форм передачі знань, таких, як філософський факультет класичного університету. Існує взаємний інтерес і взаємовплив загальної культури суспільства і філософії як особливого різновиду культури, оскільки філософія активно конфігурує інші форми культури, сприяє створенню соціокультурних ідентичностей саме завдяки своїй здатності концептуально відтворювати ядро тієї психосоціокультурної матриці, яка лежить в основі існування усіх цих розмаїтих форм у межах одного суспільства. Соціокультурний макрорівень філософських духовних практик утворює психосоціокультурна матриця філософської традиції, яка зберігає свою тяглість від виникнення філософії і йде через усю їі історію, демонструючи особливості національної рецепції філософії як національно-конкретне втілення соціокультурного макрорівня психосоціокультурної матриці філософування.

Ключові слова: людина; особистість; критичне мислення; психосоціокультурна матриця; філософування; філософська освіта; соціокультурна ідентичність; смислотворення; повсякденність

Received: 22.07.2021

Accepted: 30.11.2021 